\title{
Where backyard poultry raisers seek care for sick poultry: implications for avian influenza prevention in Bangladesh
}

Nadia Ali Rimi ${ }^{1 *}$ (D), Rebeca Sultana ${ }^{1,2}$, Kazi Ishtiak-Ahmed ${ }^{1,3}$, Najmul Haider $^{1,4}$, Eduardo Azziz-Baumgartner $^{5}$, Nazmun Nahar ${ }^{1}$ and Stephen P. Luby ${ }^{1,5,6}$

\begin{abstract}
Background: In Bangladesh, backyard poultry raisers lack awareness of avian influenza and infrequently follow government recommendations for its prevention. Identifying where poultry raisers seek care for their ill poultry might help the government better plan how to disseminate avian influenza prevention and control recommendations.
\end{abstract}

Methods: In order to identify where backyard poultry raisers seek care for their ill poultry, we conducted in-depth and informal interviews: 70 with backyard poultry raisers and six with local poultry healthcare providers in two villages, and five with government veterinary professionals at the sub-district and union levels in two districts during June-August 2009.

Results: Most (86\% [60/70]) raisers sought care for their backyard poultry locally, 14\% used home remedies only and none sought care from government veterinary professionals. The local poultry care providers provided advice and medications $(n=6)$. Four local care providers had shops in the village market where raisers sought healthcare for their poultry and the remaining two visited rural households to provide poultry healthcare services. Five of the six local care providers did not have formal training in veterinary medicine. Local care providers either did not know about avian influenza or considered avian influenza to be a disease common among commercial but not backyard poultry. The government professionals had degrees in veterinary medicine and experience with avian influenza and its prevention. They had their offices at the sub-district or union level and lacked staffing to reach the backyard raisers at the village level.

Conclusions: The local poultry care providers provided front line healthcare to backyard poultry in villages and were a potential source of information for the rural raisers. Integration of these local poultry care providers in the government's avian influenza control programs is a potentially useful approach to increase poultry raisers' and local poultry care providers' awareness about avian influenza.

Keywords: Backyard poultry raiser, Informal care provider, poultry care provider, poultry disease, Avian influenza, Perception, Bangladesh

\footnotetext{
* Correspondence: nadiarimi@icddrb.org

${ }^{1}$ Program for Emerging Infections (PEI), Infectious Diseases Division (IDD),

icddr, b, 68, Shaheed Tajuddin Ahmed Sharani, Mohakhali, Dhaka 1212,

Bangladesh

Full list of author information is available at the end of the article
}

(c) The Author(s). 2018 Open Access This article is distributed under the terms of the Creative Commons Attribution 4.0 International License (http://creativecommons.org/licenses/by/4.0/), which permits unrestricted use, distribution, and reproduction in any medium, provided you give appropriate credit to the original author(s) and the source, provide a link to the Creative Commons license, and indicate if changes were made. The Creative Commons Public Domain Dedication waiver (http://creativecommons.org/publicdomain/zero/1.0/) applies to the data made available in this article, unless otherwise stated. 


\section{Background}

Bangladesh is a country of more than 150 million people, with $64 \%$ living in rural villages [1]. Approximately $71 \%$ of the rural households raise backyard poultry [2]. Bangladeshi backyard poultry raisers come into frequent close contact with poultry every day, including touching poultry while putting them into sheds, feeding sick poultry by hand, and slaughtering poultry [3]. Since its first detection in 2007, highly pathogenic avian influenza A (H5N1) virus has become endemic in Bangladesh [4]. Eight human infections of $\mathrm{H} 5 \mathrm{~N} 1$ virus have been reported since 2008, including a fatal case [5].

In March 2007, the Government of Bangladesh organized a nationwide mass media campaign through radio, television and newspapers, and conducted public meetings through government veterinary officials at sub-district level to disseminate guidelines to prevent avian influenza infection in humans [6]. Following the campaign, a nationwide survey indicated that $49 \%$ of backyard poultry raisers recalled hearing about avian influenza during 2007 [2]. A subsequent nationally representative survey among backyard poultry raisers conducted in 2009-2012 reported that only $40 \%$ of respondents had recalled hearing about avian influenza or the government prevention guidelines [6]. Television, neighbors, family, and friends were the main sources of information about avian influenza prevention [2, 6, 7]. These studies also identified that Bangladeshi backyard poultry raisers infrequently followed government recommendations for prevention [2, 6, 7] probably because they did not recognize the disease or consider themselves at risk. The fatal case was reported after these studies, which might have contributed to low risk perception. Nevertheless, these studies suggest that existing communication channels were not optimal for reaching backyard poultry raisers or improving backyard raisers' disease risk perception.

Selecting culturally tailored messages and frequently used local communication networks might help the government improve access to poultry raisers to disseminate avian influenza prevention and control recommendations. In order to improve risk communication to people who raise poultry, this study aimed to identify where backyard poultry raisers sought advice and healthcare for their sick poultry and to explore rural poultry care providers' knowledge and perceptions about avian influenza.

\section{Methods}

During June through August in 2009, a qualitative research team collected data from one rural village from each of Rajshahi and Chittagong districts [8,9], the largest and third largest backyard poultry raising area in Bangladesh [10]. Rajshahi in the northwest and Chittagong in the southeast of Bangladesh were chosen to capture practices in two geographically and socio-culturally distinct places of the country. Villages were purposively selected because of their small size, accessibility, and being typical in the region in terms of demographic and geographic characteristics, i.e., agriculture as the main occupation, inhabitant with Muslim majority and located in floodplains. The sites were under surveillance for avian influenza and flocks had yet to test positive for $\mathrm{H} 5 \mathrm{~N} 1$ virus [11].

To explore where poultry raisers sought advice and healthcare for their sick poultry and the reasons behind their actions, the team conducted informal interviews [12] with backyard poultry raisers about diverse practices until they reached saturation [13], i.e., they repeatedly received similar information from different participants. The team conducted in-depth interviews with all local poultry healthcare providers that the raisers mentioned and all the government veterinary service providers assigned to provide veterinary care in these selected villages. The team explored local and government providers' knowledge about avian influenza, their role in the treatment of ill backyard poultry and their reasoning behind their practices. For the interviews, the team used unstructured guidelines that included topics to explore and relied on the spontaneous generation of questions during the natural flow of conversation [12]. The team invested substantial time building rapport with the informants in an effort to improve the quality of elicited information. The team recorded the interviews using audio recorders and field notes, then transcribed the recorded data verbatim and expanded the field notes. Then they reviewed the transcriptions and field notes to identify the emerging themes relevant to study objectives. They manually coded data according to themes to identify patterns and analyzed these to prepare a summary of each theme/subtheme [14]. They calculated median and inter-quartile range (IQR) for age and conducted Fisher's exact test to measure the significance of the difference in years of schooling among different groups.

\section{Results \\ Demographic information}

The team interviewed a total of 70 backyard poultry raisers, six local poultry care providers and five government veterinary service providers (Table 1$)$. Most (89\%, $62 / 70$ ) of the poultry raisers were female. The median

Table 1 Categories and number of informants interviewed in Rajshahi and Chittagong study villages, Bangladesh, 2009

\begin{tabular}{llll}
\hline Categories of informants & Rajshahi & Chittagong & Total \\
\hline Backyard poultry raisers & 25 & 45 & 70 \\
Local poultry care providers & 3 & 3 & 6 \\
Government veterinary professionals & 3 & 2 & 5 \\
\hline
\end{tabular}


age of the raisers was 38 years (IQR: $30-45)$. The majority (73\%) of the raisers had less than six years of education. All the local poultry care providers and government veterinary service providers were male. The median age of local poultry care providers was 36 years (IQR: $27-43$ ) and government veterinary service providers was 48 years (IQR: 38-52). Among the six local care providers, three had primary, two had secondary or higher secondary education and one had a Doctor of Veterinary Medicine (DVM) degree. Three of the government service providers had DVM degrees and two were Field Assistants in Artificial Insemination (FAAI) who received training on artificial insemination for cattle from government institutions after passing higher secondary examination.

\section{Local poultry care providers and government veterinary care providers}

The local poultry care providers gave advice free and sold medicine to raisers with sick poultry; four had medicine shops in the village markets, where one can buy products with or without a prescription, and two conducted household visits. Authors deliberately avoided use of the word 'pharmacy' because usually a 'pharmacy' is the part of the drug store where pharmacists process the prescriptions. In Bangladesh, there rarely exist provisions for the deliveries of professional pharmacy care practices or services in the medicine shops, where one can buy drugs, aspirin, vitamins, tissues and some other related products. One of the two mobile local poultry care providers was a non-government organization veterinarian, who also worked as a private practitioner in the area. Four of the local poultry care providers provided service for both human and animal illness.

The government had a livestock office and 1-2 registered veterinarians at each sub-district level to provide animal care. The government service providers were available for poultry care only during office hours (9 am$5 \mathrm{pm})$. In some sub-districts, there were two types of operations at the union level, which is the smallest administrative unit consisting of several villages, an artificial insemination point and a livestock welfare center. In each of our sites, there was only one field staff; this person mainly carried out artificial insemination of cattle and goats within the union. Field staff did not receive a government salary but used government resources (i.e., office space and equipment) to provide service in exchange for remuneration from the cattle owner.

The local poultry care providers were available outside of office hours and on weekends and were more accessible to the backyard raisers than were the government providers. For example, in the Rajshahi study site, there were six medicine shops in three markets within $300 \mathrm{~m}$ to $1.5 \mathrm{~km}$ of the study village (Fig. 1) and the local care providers lived inside or near the study village. In contrast, the closest government veterinary service was the artificial insemination point, which was $2.5 \mathrm{~km}$ away from the study village; the closest sub-district livestock office was located at a city $12 \mathrm{~km}$ away from the study village.

\section{Backyard poultry raisers' preference for seeking care for poultry}

Most $(86 \%, 60 / 70)$ backyard poultry raisers sought care for sick poultry from local poultry care providers. For example, many raisers from both sites purchased vitamin B2 or riboflavin for their ill poultry. Some raisers purchased paracetamol, oxytetracycline, doxycycline, chlorpheniramine, calcium supplement, contraceptive pills, metronidazole and/ or omeprazole for their flocks. A raiser shared,

"During extreme heat, a virus comes from the air once in the year and poultry also defecate white lime feces like humans get diarrhea. If it happens to one chicken in a household, it spreads to other chickens of the neighboring households. Then people feed it Maya Bori, Femicon (i.e., brand names of contraceptive pills). ' $X$ ' (an NGO) doctors taught us this and gave our chickens this tablet. Many women don't consume the contraceptive pills that the NGO workers distribute door-to-door themselves, rather feed their chickens when the chickens get sick. If anyone doesn't have the pills, she borrows it from others to feed the poultry."

Ten (14\%) of the 70 backyard poultry raisers used only home remedies. Home remedies included feeding and/or applying mustard oil, turmeric, warm rice, onion juice, juice of local herbs/leaves, soap, salt, molasses, chili powder, ginger, garlic and pain-relieving balm.

None of the 70 poultry raisers sought care from a government veterinary service provider because government livestock offices were far away and seemed to focus on large animal veterinary medicine. In contrast, mobile care providers visited the village regularly. The following quotes exemplify the preference of the raisers in both villages.

"He (the local vendor) comes everyday... He rings the bell of his bicycle and we know that he has arrived. Then I go to him and others follow... If he doesn't come... we go to the local market. Doctor $S$ and $M$ (medicine sellers at drug store) are there... They're also human doctors. If I get fever, they give me medicine. Then if I say that my chicken is sick, they also give medicine for my chicken."

"We never take backyard chickens to the livestock office. People don't go because of expenses. It is not feasible. It takes 100-200 taka (US\$ 1.3-2.6) for transportation."

"Government sends people for goats and cows only. They don't give any service for poultry... Nobody comes for backyard poultry from government offices."

\section{Local poultry care providers' perception about avian influenza, poultry illness and treatment}

Three of six local poultry care providers did not know about avian influenza. The other three local providers 


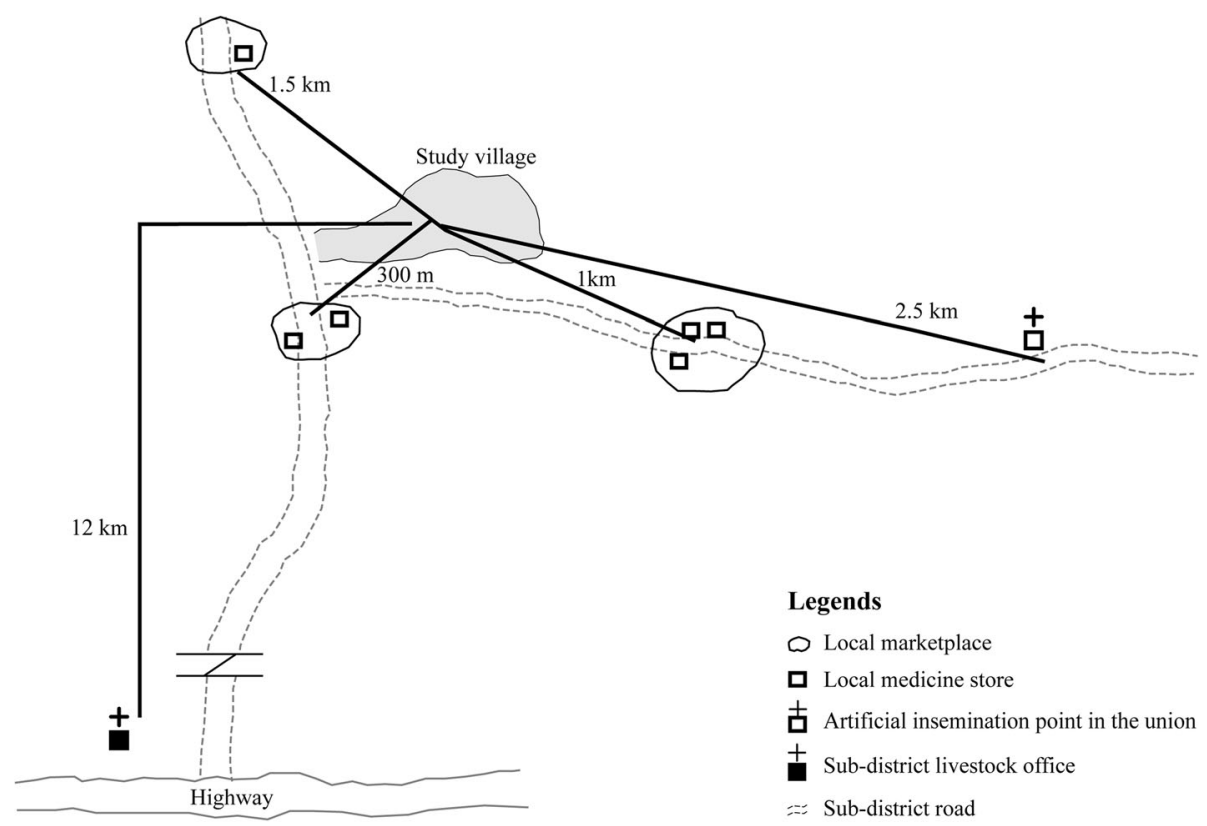

Fig. 1 Location of local medicine shops and livestock offices surrounding the Rajshahi study site, Bangladesh, 2009

considered avian influenza to be a disease common among commercial poultry but not backyard poultry. For example, one stated,

"Bird flu hasn't spread in this area yet... It was broadcasted in TV... It occurs in farm (commercial) chickens, not in these backyard poultry. It's a new disease. I don't have much awareness about this disease or its symptoms."

The local poultry care providers from both sites used similar treatment for poultry as they did for humans or cattle with similar signs. One local care provider said that he used cattle medicine for poultry because the pharmaceutical companies printed pictures of cattle and poultry on the container. He assumed this meant that the medicine could be used for both. The local care providers were also concerned about their reputation. As one said,

"The things you're asking me (about poultry disease and treatment), I can't answer. I don't have training in chicken illnesses... I take a risk when I give treatment to the poultry based on my training on cattle... It is a matter of 'maan-ijjot' (prestige/reputation) to tell people that I am a cattle doctor and I don't have training on poultry, and so cannot give treatment to the poultry.... There should be a course on poultry."

Poultry raisers were observed seeking care from local poultry care providers. While a researcher interviewed a mobile local care provider, three villagers came to him requesting medicines, one for a cow, one for a duck and one for a chicken. The local care provider reported that since government veterinarians did not come to the villages, villagers called him and that he had ample 'demand' in the area. While interviewing another local care provider at a medicine shop in the local market, the researcher observed that the local care provider provided medicine to the customer and explained the utility of the medicine.

When the customer stated, "My chicken is drowsy, and has loose stool and fever. Give me medicine", the local care provider gave the customer doxycycline and told him, "If your chicken has fever, cold or cough, it will recover. Loose stool will also recover."

Local poultry care providers from both sites mentioned prescribing a range of antibiotics for a variety of signs (Table 2). Oxytetracycline is the most frequently dispensed product by all vendors. They also mentioned using paracetamol for fever and cold. Unlike Chittagong vendors, Rajshahi vendors reported that they prescribed vitamin B2 or riboflavin for a number of signs. A vendor, who lived in the study village, said,

"Anybody who has a problem will come to my home and say, 'I have this problem. If you know what happened, give me medicine.' Or 'my chicken is not eating, it's drowsy.' Aunties come, sisters come and sisters-in-law come."

The local poultry care providers reported that they were interested in supplying services to the backyard raisers because this was an income source. A vendor said,

"There's more money in this business. Not everyone can raise cattle but all can raise poultry... you have to go by the public demand."

A local care provider shared his experience during 2007-08 when bird flu outbreaks occurred in many places of Bangladesh, 
Table 2 Drugs local poultry care providers dispensed for backyard poultry in two study villages, Bangladesh, 2009

\begin{tabular}{|c|c|c|c|c|}
\hline Trade name & Generic name & $\begin{array}{l}\text { Signs/diseases for which dispensed by } \\
\text { local care providers }\end{array}$ & Recommended usage (reference) & Quotes by local care providers \\
\hline Renamycin & Oxytetracycline & $\begin{array}{l}\text { Cholera, lime-like defecation (whitish diar- } \\
\text { rhea), liquid defecation, bloody defecation, } \\
\text { drowsiness, Newcastle Disease, fever, cold } \\
\text { (i.e., a respiratory illness), duck paralysis } \\
\text { (i.e., botulism), pneumonia, weakness, loss } \\
\text { of appetite, pox in eyes, coughing }\end{array}$ & $\begin{array}{l}\text { Salmonellosis, Colibacillosis, Infectious } \\
\text { Coryza, Chronic Respiratory Disease (CRD) } \\
\text { or Air Sac Disease, Fowl Cholera } \\
\text { (Pasteurella multocida), Necrotic Enteritis, } \\
\text { Coccidiosis [29] }\end{array}$ & \multirow{5}{*}{$\begin{array}{l}\text { "Whatever the problem may be, if they } \\
\text { (i.e., raisers) come to us, we first give } \\
\text { renamycin. Antibiotics for any disease, be } \\
\text { it cold, cough or fever... If someone hits } \\
\text { the chicken in its leg and it is injured, } \\
\text { painkiller works faster with renamycin. } \\
\text { Antibiotic is a must." } \\
\text { "In } 80 \% \text { of poultry disease, tetracycline } \\
\text { tablet like renamycin is given." } \\
\text { "If a raiser tells me that a chicken has } \\
\text { fever and the chicken is big, I suggest } \\
\text { giving a Histacin tablet, half of a Napa } \\
\text { tablet and one fourth of a renamycin } \\
\text { tablet. I advise to push the three } \\
\text { medicines down the chicken's throat with } \\
\text { a finger and then feed them some water." }\end{array}$} \\
\hline Dox-A vet & Doxycycline & $\begin{array}{l}\text { Cholera, drowsiness, lime-like defecation, } \\
\text { Newcastle Disease, fever, cold, duck par- } \\
\text { alysis, sneezing, coughing, pox in the eyes } \\
\text { and face, loose stool }\end{array}$ & $\begin{array}{l}\text { Chronic respiratory disease (CRD) and } \\
\text { mycoplasmosis [29] }\end{array}$ & \\
\hline Ciprofloxacin & Ciprofloxacin & $\begin{array}{l}\text { Drowsiness, lime-like defecation, loose } \\
\text { stool, }\end{array}$ & $\begin{array}{l}\text { Respiratory, gastrointestinal and urinary } \\
\text { tract infections [29] }\end{array}$ & \\
\hline Histacin & $\begin{array}{l}\text { Chlorphenamine } \\
\text { Maleate }\end{array}$ & Cholera, fever, cold & $\begin{array}{l}\text { Acute inflammatory and allergic } \\
\text { conditions, or febrile illness [30] }\end{array}$ & \\
\hline $\begin{array}{l}\text { Napa/ } \\
\text { Paracetamol }\end{array}$ & Acetaminophen & Fever, cold & $\begin{array}{l}\text { Fever and hyperthermia and infectious } \\
\text { diseases [30] }\end{array}$ & \\
\hline $\begin{array}{l}\text { Vitamin B2/B } \\
\text { complex }\end{array}$ & Riboflavin & $\begin{array}{l}\text { Weakness, paralysis, loss of appetite, } \\
\text { edema, decreased egg laying }\end{array}$ & $\begin{array}{l}\text { Vitamin B2 deficiency diseases including } \\
\text { curled-toe, paralyzed legs, weakness, slow } \\
\text { growth, affected egg production, diarrhea, } \\
\text { atrophied and flabby muscles, dry and } \\
\text { harsh skin, marked enlargement of the sci- } \\
\text { atic and brachial nerve sheaths [48] }\end{array}$ & \multirow{8}{*}{$\begin{array}{l}\text { "Tetracycline starts from } 250 \mathrm{mg} \text { for } \\
\text { humans. Animals and birds have to be } \\
\text { given } 500 \mathrm{mg} \text { from the very beginning." } \\
\text { "These drugs (he indicted drugs at his } \\
\text { store) are mainly for cattle, not for poultry. } \\
\text { However, drug companies have printed } \\
\text { picture of cattle, poultry, all animals on } \\
\text { the containers, which implies it can be } \\
\text { used for all." }\end{array}$} \\
\hline Metro-vet & Metronidazole & Loose stool & $\begin{array}{l}\text { Protozoan and gram negative anaerobic } \\
\text { bacterial infection [30] }\end{array}$ & \\
\hline Sandocal P & $\begin{array}{l}\text { Calcium } \\
\text { supplements }\end{array}$ & Soft, thin or missing eggshell & $\begin{array}{l}\text { Calcium deficiency including soft or no } \\
\text { shell eggs [48] }\end{array}$ & \\
\hline $\begin{array}{l}\text { Cosomix } \\
\text { plus/ ESB3 }\end{array}$ & Sulfachloropyridazine & Liquid defecation, bloody defecation & $\begin{array}{l}\text { Coccidiosis, colibacillosis, salpingitis, } \\
\text { paratyphoid infection, staphylococcal } \\
\text { infections, fowl cholera, infectious coryza } \\
\text { [30] }\end{array}$ & \\
\hline A-Fenac Vet & Diclofenac Sodium & Lime defecation, pox and insect in eyes & $\begin{array}{l}\text { Non-steriod Anti-inflammatory drugs } \\
\text { (NSAIDs) [30] }\end{array}$ & \\
\hline Hista vet & Pheniramine Maleate & Cold & $\begin{array}{l}\text { Acute inflammatory and allergic } \\
\text { conditions, or febrile illness [30] }\end{array}$ & \\
\hline Diadin & Sulphadimidine & Sore & Coccidiosis and coryza [30] & \\
\hline Cotrim vet & $\begin{array}{l}\text { Cotimoxazole } \\
\text { (Sulfamethoxazole } \\
\text { and Trimethoprim) }\end{array}$ & $\begin{array}{l}\text { Bloody defecation, lime-like defecation, li- } \\
\text { quid defecation }\end{array}$ & $\begin{array}{l}\text { Coccidiosis, salmonellosis, colibacillosis } \\
\text { [30] }\end{array}$ & \\
\hline
\end{tabular}

"At that time, people used to bring drowsy chickens. I used to give tetracycline... If 1 or 2 chickens got disease among 15-20 in a household, I told the raiser to separate the sick ones and give treatment separately... I don't know anything about its (bird flu) treatment. Veterinarians might be able to say. They (villagers) didn't know if it was bird flu."

\section{Government veterinary service providers' role and perception about avian influenza}

The government veterinary service providers had knowledge about avian influenza based on their training or experience with prevention and control. An officer said,

"Bird flu is responsible for the die-off in chickens during the last 2 years. Bird flu transmits to humans... and infects both chickens and ducks. If anyone touches and processes a bird-flu infected chicken without gloves, human can also be infected... Humans get fever and breathing difficulty."
These officials stated that there were trainings for the commercial farmers in the sub-district livestock office but not for backyard poultry raisers. The officials mentioned that they offered vaccines against Salmonella and infectious bursal disease for commercial poultry and visited commercial poultry farms in required. However, for backyard poultry, they only offered vaccines against duck plague, duck cholera, Newcastle and fowlpox and did not provide any other service to the raisers. They reported lack of staffing and an inadequate supply of medicines for backyard poultry. A Field Assistant said that people usually came to livestock offices for the treatment of cattle; nearby backyard poultry raisers sometimes visited his office because of poultry health problems but not the raisers who lived further away.

These officials reported that they also examined and culled poultry during bird flu outbreaks. An official shared his experience culling chickens during the 20072008 bird flu outbreaks. 
"We had to kill chickens the whole night. While killing 20,000 chickens at-a-stretch, my gloves and mask tore, gloves slipped in sweat and I worked without protection. I thought I would die after coming out of the farm but nothing happened to me."

A veterinarian at sub-district level shared,

"If anybody informed the upazilla (sub-district) livestock office (about poultry die off during a bird flu outbreak), villagers would rebuke that person... When we used to go to the village with police and a combined force to cull all poultry within $1 \mathrm{~km}$, villagers used to stand guard (over their flocks to resist cullers) with knives."

A veterinary surgeon at sub-district level said that they visited one or two commercial farms daily for bird flu but could not go door to door to check backyard poultry or visit backyard raisers because of inadequate staffing.

"This is an animal health center. Every union is supposed to have at least one such center but all unions do not. There are two staff; one is a VFA (Veterinary Field Assistant), who performs vaccination and provides primary treatment to the animals, and the other is a FAAI (Field Assistants in Artificial Insemination), who only performs artificial insemination. But in absence of VFA, FAAI also performs responsibilities of a VFA."

Government providers also mentioned several reasons for raisers' not coming to government veterinary officials, such as cost of transportation to livestock office, end of the government-sponsored free vaccine program, lack of awareness about government veterinary services and office hours that did not match poultry raisers' busy working hours.

\section{Discussion}

Backyard poultry raisers preferred local poultry care providers to government service providers because local providers lived closer, were available throughout the day, made house calls, were less expensive and dispensed advice and medication upon request. These findings are consistent with a systematic review that identified factors influencing care seekers to use informal providers for human health problems because of their proximity and flexible working hours [15]. Our findings suggest that local care providers could be a more effective source of communication and a more trusted source for poultry raisers compared to government counterparts and could play a role in both raising awareness among the raisers and providing practical solutions to adopt precautionary behavior. Since these local care providers belong to the community, involving them in the communication campaigns might increase community participation, incorporate local perspective to the communication, empower the community, and result in sustainable improvement in awareness and behavior.
Concern for financial gain or loss and convenience were common drivers for both the raisers and the service providers. Raisers preferred local care providers because they wanted to save money for transportation to reach government veterinarians. Since the local care providers were part of the community, villagers could easily reach them or the local providers could visit the villagers' households. Syhakhang et al. showed that $73 \%$ of women who visited drug sellers prioritized financial constraints over quality of the drugs in Lao PDR [16]. Repackaging medications into smaller and more affordable units, providing service on credit or accepting in-kind payments when patients do not have cash make the informal providers more affordable for the poor $[15,17]$. The local care providers were motivated to serve the backyard raisers for poultry problems as well as human health problems because they recognized the potential to earn a profit by dispensing medicine, as the village doctors reported in another study in Bangladesh [17]. In contrast, government veterinarians did not reach the villagers to provide care for backyard poultry and cited inadequate resource and logistic support as the major barrier. Leonard argued that permitting the government veterinarians to engage in private, fee-for-service practice in Africa provided an incentive to veterinarians to work longer hours in the rural areas [18]. However, providing service for backyard poultry might remain less attractive to government veterinarians than providing service for cattle and commercial poultry (broiler or layer chickens), since those involve higher remuneration.

Poultry raisers' care seeking behavior for ill birds reflects a trusting relationship with the local providers, which might have contributed to their ongoing consultation with them. Informal providers possess a greater degree of perceived accountability than the formal providers because of their proximity to patients; their experiences and track record are all noted within a community, resulting in trust [19]. This trust is evidenced when the raisers reached out to the local poultry care providers for help during 2007-08 when avian influenza outbreaks occurred in many places of Bangladesh. Interpersonal communication is more effective in situations of poor literacy and low awareness than other channels of communication [20,21]. A study on sources of information and health beliefs related to SARS and avian influenza among Chinese communities suggested that information from trusted sources, such as family and friends, contributed more to the risk perception than information from other formal sources, such as doctors and government agencies [22].

In contrast, despite knowledge and institutional training on poultry healthcare, government service providers were often perceived as distant and unwilling to accept responsibility for their services [23]. In rural Cambodia, 
farmers were reluctant to have their large animals vaccinated by government veterinary service providers, even when these services were provided at low subsidized costs, but were more willing to have their animals vaccinated by Village Livestock Agents [23]. The lack of government involvement in veterinary care of backyard poultry also means the government may be unaware of poultry die-offs. A study in Nigeria indicated that $57 \%$ of respondents with knowledge of avian influenza were unwilling to inform authorities of sudden and massive deaths among their flocks because of fear of culling of birds without compensation (75\%) [24]. A survey in Bangladesh showed only 3\% of respondents reported unusual poultry deaths to authorities, $73 \%$ did not know how to report poultry deaths and $24 \%$ did not think reporting was important [6]. As mentioned by a government official in this study, poultry culling activities during avian influenza outbreaks in 2007-08 in Bangladesh had a negative repercussion among the poultry raisers [7]. Poorly executed compensation strategies might have further weakened poultry raisers' trust in the government and discouraged reporting unexplained flock mortality [25]. Political science scholars have noted that residents of Bangladesh generally view their government as corrupt and primarily serving the interest of government workers rather than the general public [26]. In a nationally representative survey, two thirds of Bangladeshi residents reported paying a bribe to a government official within the prior 12 months [27]. In this low trust context, it is unsurprising that poultry raisers put little trust in government veterinarians.

It is difficult to assess appropriateness of the treatments prescribed by local poultry care providers without laboratory diagnosis. The vendors reported dispensing antibiotics indiscriminately, which might increase antibiotic resistance, a global concern for both human and animal health [28], and a motivation for calls to reduce irrational antibiotic use. Medications are available for most bacterial and protozoan poultry diseases, including fowl cholera (Pasteurella multocida), salmonelloses, infectious coryza and coccidiosis infection [29, 30]. Viral diseases, including avian influenza, Newcastle disease, infectious bursal diseases, and infectious bronchitis, may be fatal for poultry and there is no specific antiviral treatment [31, 32]. Vaccination and improving biosecurity are keys to the prevention and control of infections in backyard poultry [33, 34]. The Government of Bangladesh produces a limited quantity of vaccine for Marek's disease, Newcastle disease, fowl pox, pigeon pox, fowl cholera, salmonellosis, infectious bursal disease and duck plague [35], though none of the backyard raisers interviewed in these villages reported using these vaccines. The Drug Administration authority of the Government of Bangladesh has allowed restricted use of avian influenza vaccines for commercial poultry since 2014 [36], although their use is controversial because vaccinated birds can still become infected and shed viruses with few or no clinical signs of infection [37].

Local healthcare providers have been previously identified as an important source of healthcare services and influence customers' care seeking behavior for human illness in low income countries [38-41], including Bangladesh, particularly among rural, poor and underserved populations $[15,42]$. A systematic review reported that educational interventions, including capacity-building training programs for informal healthcare providers, was the most common recommendation by the authors [15]. Lack of academic or institutional training decreases the appropriateness of local healthcare providers' recommendations [39, 40]. Recognition of a legitimate role for these informal providers is likely to provoke resistance by government sanctioned professionals which play the role of "a guarantor of standards" but are also strongly motivated to secure profits, power and privilege [43]. National health development strategies have typically ignored the existence of informal healthcare providers [42], which might result in little support to backyard poultry raisers in resource-poor settings. As Sims argues, in a country like Bangladesh, certain factors, such as complex nature of the poultry production and marketing systems, limited veterinary capacity and low level of commitment from the raisers to country-wide elimination of virus to central government, favored persistence of virus [44]. In such a scenario, co-operation between government service providers and local care providers rather than mutual exclusion, might be a better approach $[18,42]$ to increase veterinary service capacity to communicate recommendations to prevent avian influenza and promote biosecurity.

This research was conducted in only two sub-districts, so it may not be representative of all backyard poultry raisers or veterinary care providers of Bangladesh. Nevertheless, since responses from our study participants are consistent with behaviors of care seekers and care providers in other Bangladeshi rural communities for poultry $[45,46]$ and humans $[17,41]$, these findings are likely applicable to other similar settings. Some government veterinary service providers were reluctant to share information and the team could not corroborate some of the assertions villagers or local care providers made. The study was conducted in 2009 and there was only one reported $\mathrm{H} 5 \mathrm{~N} 1$ case prior to the data collection of this study, hence it is possible that occurrence of the latter cases, including a fatal one, might have influenced raiser' risk perception and care seeking practices since then. However, since we did not find substantial differences in people's awareness on avian influenza reported 
in surveys conducted in 2007 [2] and 2014 [47], we assume that our conclusions remain applicable. Another qualitative study that explored biosecurity practices among small commercial chicken farms during 2011-12 showed similar reliance on these local care providers [46].

\section{Conclusions}

For a resource-poor country like Bangladesh, the local poultry care providers play an important role in providing care to backyard poultry in villages. The credibility of these vendors is linked to their relationship with the poultry raisers and reinforced by the structure of incentives. These vendors could be a useful channel to implement health promotion interventions among backyard and small commercial poultry raisers [46] because they serve both groups and are available at the village level all over the country. Local poultry care providers might also serve as a bridge between government authority and the rural raisers, since they are the persons to whom raisers reach-out for help when their birds are sick. Developing interventions to increase the knowledge and skill of these local vendors through institutional training and integrating them in the government's avian influenza control programs is a potentially useful approach that should be evaluated.

\section{Abbreviations}

IQR: inter-quartile range; DVM: Doctor of Veterinary Medicine.; FAAI: Field Assistants in Artificial Insemination.; VFA: Veterinary Field Assistant.

\section{Acknowledgements}

We are grateful to our study participants for their time and invaluable information. We thank Marufa Hasin, Afroza Khanam Roza and Md. Zahidur Rahman for their valuable contribution in developing guidelines and data collection and Mahbub ul Alam for his contribution in drawing the location map [Fig. 1]. We also thank Rashid Zaman for their contribution in developing the research protocol. We thank Diana DiazGranados for editing the manuscript. We thank Jerome Tokars, Susan Trock, and Sonja Olsen for their thorough and expedient feedback.

\section{Funding}

This research was funded by the Centers for Disease Control and Prevention (CDC) (https://www.cdc.gov/) under the Cooperative Agreement Grant 5U51-Cl000298. icddr, b acknowledges with gratitude the commitment of CDC to its research efforts. SPL received the funding. The paper was reviewed and cleared for publication by independent CDC staff who were not involved in study design, data collection and analysis, decision to publish, or preparation of the manuscript. The opinions expressed by authors contributing to this journal do not necessarily reflect the opinions of CDC or the institutions with which the authors are affiliated. icddr, b is also grateful to the Governments of Bangladesh, Canada, Sweden and the United Kingdom for providing core/unrestricted support.

\section{Availability of data and materials}

The dataset supporting the conclusions of this article are included within the article and its additional files.

\section{Authors' contributions}

$N A R, R S, E A B, N N$ and SPL conceived and designed the study. NAR and KIA contributed to data collection. NAR, RS, KIA, NH and SPL contributed to data analysis. NAR lead the writing of the manuscript, SPL guided the writing as the senior author and all authors contributed to writing the manuscript. All authors read and approved the final manuscript.

\section{Ethics approval and consent to participate}

We received approval of the study protocol from icddr, b's Ethical Review Committee (FWA \# 00001468, Human Welfare Assurance \# 00001822). All participants provided verbal informed consent for enrollment into the study. A Centers for Disease Control and Prevention (CDC) institutional review board concluded that the agency was not engaged with human subjects in this project.

\section{Consent for publication}

Not applicable.

\section{Competing interests}

The authors declare that they have no competing interests.

\section{Publisher's Note}

Springer Nature remains neutral with regard to jurisdictional claims in published maps and institutional affiliations.

\section{Author details \\ ${ }^{1}$ Program for Emerging Infections (PEI), Infectious Diseases Division (IDD), icddr, b, 68, Shaheed Tajuddin Ahmed Sharani, Mohakhali, Dhaka 1212, Bangladesh. ${ }^{2}$ Department of Public Health, University of Copenhagen, Copenhagen, Denmark. ${ }^{3} U$ niversity of Copenhagen, Copenhagen, Denmark. ${ }^{4}$ Technical University of Denmark, Copenhagen, Denmark. ${ }^{5}$ Centers for Disease Control and Prevention (CDC), Atlanta, GA, USA. ${ }^{6}$ Stanford University, Stanford, California, USA.}

Received: 19 December 2017 Accepted: 10 July 2018 Published online: 03 August 2018

\section{References}

1. Agriculture \& Rural Development https://data.worldbank.org/indicator/SP. RUR.TOTL.ZS?display=graph\&locations=BD. Accessed 15 July 2018.

2. UNICEF Bangladesh. Avian influenza knowledge, attitude and practice (KAP) survey among the general public and poultry farmers in Bangladesh; 2007.

3. Sultana R, Nahar N, Rimi NA, Azad S, Islam MS, Gurley ES, Luby SP. Backyard poultry raising in Bangladesh: a valued resource for the villagers and a setting for zoonotic transmission of avian influenza. A qualitative study. Rural Remote Health. 2012;12:1927.

4. Loth L, Gilbert M, Osmani MG, Kalam AM, Xiao X. Risk factors and clusters of highly pathogenic avian influenza H5N1 outbreaks in Bangladesh. Prev Vet Med. 2010;96(1-2):104-13.

5. Cumulative number of confirmed human cases for avian influenza A (H5N1) reported to WHO, 2003-2018. http://www.who.int/influenza/human_animal_ interface/2018_05_28_tableH5N1.pdf?ua=1. Accessed 15 July 2018.

6. Shanta IS, Hasnat MdA, Zeidner N, Gurley ES, Azziz-Baumgartner E, Sharker MAY, Hossain K, et al. Raising backyard poultry in rural Bangladesh: financial and nutritional benefits, but persistent risky practices. Transbound Emerg Dis. 2017;64(5):1454-64.

7. Sultana R, Rimi NA, Azad S, Islam MS, Khan MS, Gurley ES, Nahar N, Luby SP. Bangladeshi backyard poultry raisers' perceptions and practices related to zoonotic transmission of avian influenza. J Infect Dev Ctries. 2012;6(2):156-65.

8. Rimi NA, Sultana R, Ishtiak-Ahmed K, Khan SU, Sharker MAY, Zaman RU, Azziz-Baumgartner E, Gurley ES, Nahar N, Luby SP. Poultry slaughtering practices in rural communities of Bangladesh and risk of avian influenza transmission: a qualitative study. EcoHealth. 2014;11(1):83-93.

9. Rimi NA, Sultana R, Ishtiak-Ahmed K, Rahman MZ, Hasin M, Islam MS, et al. Understanding the failure of a behavior change intervention to reduce risk behaviors for avian influenza transmission among backyard poultry raisers in rural Bangladesh: a focused ethnography. BMC Public Health. 2016;16(1):858.

10. Dolberg F. Poultry sector country review: Bangladesh. 2008.

11. Follow-up report No 43 (Final Report). http://www.oie.int/wahis_2/ public\%5C..\%5Ctemp\%5Creports/en_fup_0000014568_20131223_145541. pdf. Accessed 15 July 2018.

12. Patton MQ. Qualitative evaluation and research methods. Beverly Hills, CA: SAGE Publications; 1990

13. Guest G, Bunce A, Johnson L. How many interviews are enough? An experiment with data saturation and variability. Field methods. 2006; 18(1):59-82. 
14. Vaismoradi M, Turunen $\mathrm{H}$, Bondas $\mathrm{T}$. Content analysis and thematic analysis: implications for conducting a qualitative descriptive study. Nurs Health Sci. 2013;15(3):398-405.

15. Sudhinaraset $M$, Ingram M, Lofthouse HK, Montagu D. What is the role of informal healthcare providers in developing countries? A systematic review. PLoS One. 2013;8(2):e54978.

16. Syhakhang L, Freudenthal S, Tomson G, Wahlström R. Knowledge and perceptions of drug quality among drug sellers and consumers in Lao PDR. Health Policy Plan. 2004;19(6):391-401.

17. Bhuiya A. Health for the rural masses. Dhaka: ICDDR, B; 2009.

18. Leonard D, Koma L, Ly C, Woods P. The new institutional economics of privatising veterinary services in Africa. Rev Sci Tech (International Office of Epizootics). 1999;18(2):544-61.

19. Ensor T, Witter $\mathrm{S}$. Health economics in low income countries: adapting to the reality of the unofficial economy. Health Policy. 2001;57(1):1-13.

20. Ahmed SM, Hossain MS, Kabir M. Conventional or interpersonal communication: which works best in disseminating malaria information in an endemic rural Bangladeshi community? PLoS One. 2014;9(6):e90711.

21. Cropley $L$. The effect of health education interventions on child malaria treatment-seeking practices among mothers in rural refugee villages in Belize, Central America. Health Promot Int. 2004;19(4):445-52.

22. Voeten HA, de Zwart O, Veldhuijzen IK, Yuen C, Jiang X, Elam G, Abraham T, Brug J. Sources of information and health beliefs related to SARS and avian influenza among Chinese communities in the United Kingdom and the Netherlands, compared to the general population in these countries. Int J Behav Med. 2009;16(1):49-57.

23. Ballard BM. Farm-level bureaucrats in action (and inaction): the distribution of veterinary services in Laos and Cambodia. PhD diss., Massachusetts Institute of Technology. 2005.

24. Musa OI, Aderibigbe SA, Salaudeen GA, Oluwole FA, Samuel SO. Community awareness of bird flu and the practice of backyard poultry in a north-central state of Nigeria. J Prev Med Hyg. 2010;51(4):146-51.

25. Chakma D, Rushton J. Rapid assessment on socio-economic impact due to highly pathogenic avian influenza in Bangladesh. Report submitted to FAO. 2008:35.

26. Zafarullah $\mathrm{H}$, Siddiquee NA. Dissecting public sector corruption in Bangladesh: issues and problems of control. Public Organization Review. 2001;1(4):465-86.

27. Knox C. Dealing with sectoral corruption in Bangladesh: developing citizen involvement. Public Adm Dev. 2009;29(2):117-32.

28. Laxminarayan R, Duse A, Wattal C, Zaidi AK, Wertheim HF, Sumpradit N, et al. Antibiotic resistance-the need for global solutions. Lancet Infect Dis. 2013:13(12):1057-98.

29. Pattison M. Poultry diseases, Sixth edn: Elsevier Health Sciences; 2008.

30. Krautwald-Junghanns M, Orosz SE, Tully T Jr. Essentials of avian medicine and surgery. third ed: Wiley; 2008

31. David E, Swayne JRG, McDougald LR, Nolan LK, Suarez DL, Nair VL. Diseases of poultry. 13th ed: Wiley-Blackwell; 2013.

32. Speer BL. Current therapy in avian medicine and surgery. 1st ed. St. Louis: Elsevier health sciences; 2015.

33. Thekisoe M, Mbati P, Bisschop S. Different approaches to the vaccination of free ranging village chickens against Newcastle disease in Qwa-Qwa, South Africa. Vet Microbiol. 2004;101(1):23-30.

34. Kelly PJ, Chitauro D, Rohde C, Rukwava J, Majok A, Davelaar F, Mason PR. Diseases and management of backyard chicken flocks in Chitungwiza, Zimbabwe. Avian Dis. 1994;38(3):626-9.

35. Livestock Research Institute. Poshupakhir rog protishedhok tika: utpadon, shongrokkhon o bebohaar nirdeshika (Disease preventive vaccines for livestock and poultry: instructions for production, preservation and dosage). Dhaka: Department of Livestock Services.

36. Bangladesh: avian influenza immunization Program http://www.poultrymed. com/Poultrymed/Templates/showpage.asp?DBID=1\&LNGID=1\&TMID= 178\&FID=1585\&PID=0\&IID=3418. Accessed 11 Nov 2015.

37. Swayne DE. Impact of vaccines and vaccination on global control of avian influenza. Avian Dis. 2012;56(4s1):818-28.

38. Igun U. Why we seek treatment here: retail pharmacy and clinical practice in Maiduguri, Nigeria. Soc Sci Med. 1987;24(8):689-95.

39. Smith $\mathrm{F}$. The quality of private pharmacy services in low and middle-income countries: a systematic review. Pharm World Sci. 2009;31(3):351-61.

40. Goel P, Ross-Degnan D, Berman P, Soumerai S. Retail pharmacies in developing countries: a behavior and intervention framework. Soc Sci Med. 1996;42(8):1155-61.
41. Ahmed SM, Adams AM, Chowdhury M, Bhuiya A. Changing health-seeking behaviour in Matlab, Bangladesh: do development interventions matter? Health Policy Plan. 2003;18(3):306-15.

42. Bloom G, Standing H, Lucas H, Bhuiya A, Oladepo O, Peters DH. Making health markets work better for poor people: the case of informal providers. Health Policy Plan. 2011;26(suppl 1):i45-52.

43. Dussault $\mathrm{G}$. The health professions and the performance of future health systems in low-income countries: support or obstacle? Soc Sci Med. 2008; 66(10):2088-95

44. Sims LD. Intervention strategies to reduce the risk of zoonotic infection with avian influenza viruses: scientific basis, challenges and knowledge gaps. Influenza Other Respir Viruses. 2013;7(Suppl 2):15-25.

45. Roess AA, Winch PJ, Ali NA, Akhter A, Afroz D, El Arifeen S, Darmstadt GL, Baqui AH, Bangladesh PSG. Animal husbandry practices in rural Bangladesh: potential risk factors for antimicrobial drug resistance and emerging diseases. Am J Trop Med Hyg. 2013;89(5):965-70.

46. Rimi NA, Sultana R, Muhsina M, Uddin B, Haider N, Nahar N, Zeidner N, Sturm-Ramirez K, Luby SP. Biosecurity conditions in small commercial chicken farms, Bangladesh 2011-2012. EcoHealth. 2017;14(2):244-58.

47. Sarker S, Sumon S, Khan MA, Islam M. Knowledge, attitude and practices survey on avian influenza in three districts of Bangladesh. Bangladesh Journal of Veterinary Medicine. 2016;14(1):27-36.

48. Cole DJA, Haresign W. Recent developments in poultry nutrition. Oxford, United Kingdom: Butterworth-Heinemann; 2013.
Ready to submit your research? Choose BMC and benefit from:

- fast, convenient online submission

- thorough peer review by experienced researchers in your field

- rapid publication on acceptance

- support for research data, including large and complex data types

- gold Open Access which fosters wider collaboration and increased citations

- maximum visibility for your research: over $100 \mathrm{M}$ website views per year

At BMC, research is always in progress.

Learn more biomedcentral.com/submissions 